\title{
LIMITES ÉTICOS A PATENTES BIOTECNOLÓGICAS
}

\section{ETHICAL LIMITS ON BIOTECHNOLOGICAL PATENTS}

\author{
Alexandra Barbosa de Godoy Corrêa ${ }^{1}$
}

\section{RESUMO}

Ao serem implementadas necessárias modificações no artigo 18, inciso III da Lei de Propriedade Industrial Brasileira, possibilitando, destarte, a ampliação do patenteamento em biotecnologia, permitindo a proteção sobre seres vivos, inevitável será a eclosão de inúmeras discussões no campo ético. Sendo assim, este estudo tem por objetivo analisar os possíveis limites que deverão existir ao patenteamento da vida. Quanto a sua metodologia, trata-se de uma pesquisa básica e qualitativa que visa a gerar discussões e conhecimentos novos úteis para o avanço da ciência. Em relação aos objetivos, trata-se de uma pesquisa exploratória que proporciona maior familiaridade com o assunto, e no que diz respeito aos procedimentos técnicos, a metodologia utilizada foi a pesquisa bibliográfica, em que se procura explicar e discutir o tema com base em referências teóricas nacionais e internacionais, publicadas em livros, artigos científicos, teses, além de vasta pesquisa documental de leis, tratados e jurisprudência. O estudo, por fim, é baseado no método dedutivo, em que premissas levantadas a partir dos autores do estudo teórico forneceram fundamento para a conclusão de que a escolha por um sistema forte que estimule e garanta a inovação é essencial, porém limites éticos devem existir para assegurar a dignidade e integridade do ser humano.

Palavras-Chave: Bioética; Biotecnologia; Patentes; Propriedade Industrial; Dignidade Humana

\begin{abstract}
As fundamental changes are implemented to article 18, item III of the Brazilian Industrial Property Law, thus enabling the expansion of patenting in biotechnology and therefore contributing to the protection of living beings, it will be inevitably the outbreak of numerous discussions in the ethical field. Accordingly, this study aims to analyze the possible limits that shall appear to the patenting of life. Concerning its methodology, it is a basic and qualitative research that intends to generate discussions and new knowledge useful for the advancement of science. As regards to the objectives, this is an exploratory analysis that provides greater familiarity with the subject. Ultimately, in terms of technical procedures, we used the bibliographical research metodology, in order to explain and discuss the theme based on national and international theoretical references, published in books, scientific

\footnotetext{
${ }^{1}$ Doutora e mestre em Direito pela Universidade Estácio de Sá com doutorado sanduíche na Universidade de Padova- Itália. Professora universitária. Membro do grupo de pesquisa em Bioética da Universidade Veiga de Almeida, pesquisadora do Research Group on Global Comparative Law: Governance, Innovation and Sustainability e do LEDH. Universidade Veiga de Almeida - UVA, Rio de Janeiro - Brasil. Lattes: http://lattes.cnpq.br/3837745888907948 E-mail: alexandra.correa@ mackenzie.br
} 
articles, theses, as well as extensive documentary research on laws, treaties and jurisprudence. Finally, this paper is based on the deductive method, in which assumptions raised from the authors of the theoretical study contributed to the belief that the choice for a strong system that stimulates and guarantees innovation is essential, but ethical limits must exist to ensure the dignity and integrity of the human being.

Keywords: Bioethics; Biotechnology; Patents; Industrial Property, Human Dignity.

\section{INTRODUÇÃO}

A biotecnologia é a tecnologia baseada na biologia, ou seja, qualquer aplicação tecnológica que utilize organismos vivos ou seus derivados, com o fim de resolver problemas e criar produtos de utilidade. Neste conceito se enquadram um conjunto de atividades que o homem já vem desenvolvendo há milhares de anos, como a produção de alimentos fermentados (pão, vinho, iogurte, cerveja e outros). A biotecnologia contemporânea faz uso da informação genética, incorporando técnicas de DNA recombinante ${ }^{2}$.

A expansão da biotecnologia, e por causa da novidade da matéria e da sua direta incidência sobre a vida, surge como relevantes os problemas éticos, com particular referência às consequências potencialmente incompatíveis com a tutela dos direitos fundamentais do homem. A ética e o direito são os instrumentos responsáveis por guiar a sociedade civil para que seja capaz de aproveitar ao máximo os possíveis benefícios provenientes dos avanços científicos sem, contudo, violar preceitos como dignidade humana, vida, liberdade, integridade física e etc...

A Bioética possui a finalidade de estabelecer parâmetros éticos para as pesquisas e para as novas tecnologias. A Bioética consiste nos critérios e teorias sobre o comportamento correto, ou seja, na prudência genética, em condutas responsáveis de forma a garantir a existência futura, enquanto, que o Direito (Biodireito), consiste no caráter coercitivo, impondo limites às condutas humanas através de suas normas. A Bioética representa um estudo acerca da conduta humana no campo da vida e da saúde humana, e do perigo de interferência nesse campo em virtude de avanços das pesquisas biomédicas e tecnocientíficas. Cuida-se, a partir da ótica da Bioética, de orientar a conduta humana nas áreas das ciências da vida, com o objetivo de imprimir, em tais condutas, certos valores e

${ }^{2}$ DNA recombinante consiste na transferência de um gene de um organismo para outro, ou seja, a recombinação de DNA proveniente de diferentes fontes. A tecnologia do DNA recombinante é um conjunto de técnicas que permitem a manipulação do DNA. 
princípios morais. Nesse sentido, há que se compreender a Bioética como uma ética aplicada às várias dimensões da vida humana (FABRIZ, 2003).

A Bioética pretende encontrar respostas específicas aos novos problemas da biomedicina, incluindo a biotecnologia. Constitui-se em fonte e parâmetro de referência, tanto para o cientista, como para o cidadão comum, além de configurar-se como poderosíssimo instrumento intelectual de reflexão na elaboração de critérios de orientação e de tomada de decisão, oponíveis às tentações dos excessos praticados pelo Estado e pelos próprios pesquisadores.

Com os avanços biotecnológicos, o direito à vida tem sido objeto de várias indagações interdisciplinares, a fim de se destacar as relações entre as diversas possibilidades de sua manipulação e as questões de ordem moral, social e jurídica. Para Fabriz (2003, p.273), "se às ciências da vida cabe o livre exercício da especulação em torno das várias possibilidades de elementos que integram a vida, cabe ao Direito proceder ao enquadramento legal, no sentido de se preservar a integridade da vida e da pessoa humana".

Importante destacar que a questão central deste estudo, ou seja, sua essência, não está em discutir como conviver com as novas tecnologias, e nem mesmo sobre os limites éticos da pesquisa em biotecnologia, e, sim, sobre os limites éticos do patenteamento da vida, mais precisamente de genes humanos, expressão geralmente utilizada para se referir à atribuição do direito de propriedade industrial, através das patentes, às invenções biotecnológicas. Estas ensejam questões novas para o mundo do direito de propriedade e para a Bioética.

Hoje o Brasil já discute - à luz da política tecnológica e industrial e do nível de desenvolvimento científico, tecnológico e industrial - o nível de proteção oferecido pela Lei de Propriedade Industrial (Lei 9279/96).

Em princípio, a invenção biotecnológica tem direito à mesma forma de proteção de todas as invenções; ou seja, elas não apresentam diferenças substanciais em comparação às inanimadas, enquanto possuírem a possibilidade de satisfazer aos requisitos do sistema de patentes. A exclusão da patente para invenções biotecnológicas só se justifica se houver obstáculos legais ou éticos na verificação de sua concessão.

Quando o material biológico origina-se do homem, a dimensão ética definitivamente ganha vantagem, porque é uma questão de identificar critérios para inspirar escolhas normativas que venham a salvaguardar a dignidade da pessoa e da integridade do seu patrimônio genético. A exploração do material biológico de origem humana exige sempre o respeito aos direitos fundamentais e da dignidade humana (DI LELLA, 2013). 
A concessão de patentes para invenções biotecnológicas é pacífica; porém, surge uma dificuldade, do ponto de vista ético, sobre os seus limites, uma vez que se está lidando com vidas. É evidente que o legislador deve inserir limites ao agir humano, para tutelar interesses considerados superiores, como a dignidade humana e a integridade física, e, portanto, que não podem ser prejudicados pelos interesses científicos e técnicos.

Ao serem implementadas necessárias modificações no artigo 18, inciso III da Lei de Propriedade Industrial Brasileira, possibilitando, destarte, a ampliação do patenteamento em biotecnologia, permitindo a proteção sobre seres vivos, inevitável será a eclosão de inúmeras discussões no campo ético. Sendo assim, este estudo tem por objetivo analisar os possíveis limites que deverão existir ao patenteamento da vida, ou seja, ao patenteamento de seres vivos.

Este estudo, quanto a sua metodologia, trata-se de uma pesquisa básica que objetiva gerar discussões e conhecimentos novos úteis para o avanço da ciência. Qualitativa, quanto a abordagem. Quanto aos objetivos trata-se de uma pesquisa exploratória proporcionando uma maior familiaridade com o assunto e quanto aos procedimentos técnicos, a metodologia utilizada foi a pesquisa bibliográfica, em que se procura explicar e discutir o tema com base em referências teóricas nacionais e internacionais, publicadas em livros, artigos científicos, teses, além de uma vasta pesquisa documental de leis, tratados e jurisprudência.

O estudo, por fim, é baseado no método dedutivo, em que premissas levantadas a partir dos autores do estudo teórico, forneceram um fundamento para a conclusão de que a escolha por um sistema forte que estimule e garanta a inovação é essencial, porém limites éticos devem existir para assegurar a dignidade e integridade do ser humano.

\section{A BIOTECNOLOGA NO TERCEIRO MILÊNIO}

A Biotecnologia é definida, pela Convenção sobre Diversidade Biológica da ONU, de acordo com o artigo $2^{\circ}$ - tratado da Organização das Nações Unidas relacionado ao meio ambiente -, como "qualquer aplicação tecnológica que utilize sistemas biológicos, organismos vivos, ou seus derivados, com o fim de resolver problemas e criar produtos de utilidade" (MINISTÉRIO DO MEIO AMBIENTE, 2015).

Stella Mara Martínez (1998) conceitua a biotecnologia como o conjunto de técnicas de recombinação genética que utilizam organismos vivos, ou substâncias deles derivadas, para fabricar ou modificar um produto, para melhorar as características das plantas e animais 
importantes a partir do ponto de vista econômico, ou para criar microrganismos que atuem sobre o meio ambiente.

Leo Pessini e Christian de Paul de Barchifontaine (2010) escrevem que a biotecnologia é entendida como um conjunto de técnicas e processos biológicos que possibilitam a utilização da matéria viva para degradar, sintetizar e produzir outros materiais. Engloba a elaboração das próprias técnicas, processos e ferramentas, assim como o melhoramento e a transformação das espécies, via seleção natural.

Segundo ainda esses autores, as técnicas e os processos que viabilizam a manipulação do código genético da molécula de DNA constituem, hoje, um ramo importante da denominada Engenharia Genética. Chama-se "Engenharia Genética" a Biotecnologia que trabalha diretamente com o DNA.

Para Dias e Cerda (2016), a biotecnologia pode envolver a produção de novas substâncias a partir da exploração de organismos vivos ou parte destes. Por meio do uso de técnicas e conhecimentos decorrentes da bioquímica, da engenharia genética, da microbiologia, da química, da física, da matemática, e até mesmo da ciência da computação, a biotecnologia é um instrumento para a inovação, o desenvolvimento humano e a inserção de novos processos industriais.

Já em uma definição ampla, biotecnologia é o uso de organismos vivos, ou parte deles, para a produção de bens e serviços. Neste conceito se enquadram um conjunto de atividades que o homem vem desenvolvendo há milhares de anos, como a produção de alimentos fermentados (pão, vinho, iogurte, cerveja e outros). Por outro lado, a biotecnologia moderna é considera como aquela que faz uso da informação genética, incorporando técnicas de DNA recombinante (CARVALHO, 2014).

A concessão de patentes e genes, linhas de células, tecidos geneticamente desenvolvidos, órgãos e organismos, bem como os processos usados para alterá-los, estão proporcionando ao mercado um incentivo comercial para se explorar os novos recursos. As modernas aplicações da biotecnologia resultam de investigações e estudos interdisciplinares com amplo interesse nas áreas das ciências da vida, como: medicina, farmácia, agricultura, pecuária, biotecnologia do meio ambiente; ou seja, ciências que vão da medicina à agricultura e que estão sendo consolidadas sob a proteção de gigantescas empresas da "vida" nos mercados biotecnológicos emergentes (RIFIKIN, 1999).

O século XX foi considerado o "século biotecnológico", pois trouxe uma nova base de recursos, um novo grupo de tecnologias transformadoras, novas formas de proteção 
comercial. As novas tecnologias genéticas permitem combinar material genético além das fronteiras naturais, reduzindo a vida a um material químico manipulável. Esta nova forma radical de manipulação biológica muda o conceito de natureza e sua relação com o homem. Após milhares de anos fundindo, derretendo, soldando, forjando e queimando a matéria inanimada para se criar coisas úteis, agora o homem está juntando, recombinando, inserindo e costurando material vivo, e construindo utilidades econômicas. Assim como se manipula plásticos e metais, agora é possível manufaturar materiais vivos (RIFKIN, 1999).

$\mathrm{O}$ presente século (XXI), marcado pela biotecnologia, destaca-se também pelas interferências frequentes na vida de todos os seres. Para melhor compreensão do tema, são esclarecedoras as ponderações de Jeremy Rifkin (1999) sobre os sete fios que compõem a matriz operacional do novo século biotecnológico, a saber: 1) reservatório de genes - uma vez isolados, identificados, recombinados, tornam-se recursos primários brutos para a futura atividade econômica, com o fim de manipular e explorar os recursos genéticos; 2) patentes de vida - constituem-se num incentivo para o mercado para exploração desses novos recursos, no caso de se conceder o patenteamento de genes, linha de células, tecido geneticamente desenvolvido, órgãos e organismos, bem como os processos usados para alterá-los; 3 ) globalização de empresa da vida - trata-se da segunda gênese: a vida concebida em laboratório. E, ainda, alerta-nos sobre a consolidação e globalização das empresas da vida ao atuarem nos recursos biológicos do planeta; 4) mapeamento do genoma humano possibilita a alteração da espécie humana e o nascimento de uma civilização comercialmente eugênica; 5) novas correntes culturais - a nova sociobiologia propiciará a ampla aceitação das novas biotecnologias; 6) fusão entre as tecnologias da computação e a genética; 7) e uma nova narrativa cosmológica sobre a evolução.

A Biotecnologia Genética constitui-se num poderoso instrumento de contribuição para as anteriores formas de luta contra enfermidades, assim como para sanar desequilíbrios do funcionamento bioquímico do organismo. Frente aos antigos procedimentos, a genética oferece hoje maiores possibilidades e técnicas muito mais precisas e eficazes. Contudo, imprevisíveis são seus efeitos e frequentemente incontroláveis. Com isso, a sua utilização, assim como a investigação que a sustenta, devem ser compatíveis com a adoção de precauções e medidas de segurança no manuseio da matéria viva, mais ainda quando for objeto de modificações genéticas, cujas interferências em outros seres vivos, incluindo o ser humano, são de prognóstico inesperados. O Direito vê-se comprometido na proteção jurídica das conquistas das investigações e, em especial, dos novos produtos que, ao versar sobre 
matéria viva, oferecem perfis distintos e de difícil assimilação pelos instrumentos jurídicos tradicionais, principalmente nos casos em que mesclam formulações de natureza ética com interesses econômicos (CASABONA, 1999).

Os novos campos da pesquisa, das descobertas e das técnicas de engenharia genética; ou seja, todos esses avanços prodigiosos, levantaram, desde cedo, um feixe de problemas e desafios éticos que a consciência humana apenas começa a abarcar e a enfrentar na sua totalidade. Para Josaphat (2010, p.394), "um novo saber sobre o ser humano, um novo saber fazer se implantam, tendo por objeto a existência, os limites e as qualidades da própria vida humana".

A ciência, por si só, não é suficiente para se alcançar o âmbito ontológico da manifestação dos valores que consubstanciam o agir humano a fim de se projetar referenciais éticos para a produção científica e a manipulação da natureza. A falta de referenciais éticofilosóficos para a ciência contemporânea impede que ela possa se posicionar adequadamente diante dos problemas que surgem da sua própria produção. Por isso, a necessidade do exame dos princípios da bioética surgiu com a finalidade de estabelecer parâmetros éticos para as pesquisas e tecnologias, e terminaram por receber sua formalização, mais universal, sob a forma de direitos humanos ("Declaração Universal sobre o Genoma e os Direitos Humanos", UNESCO, 1997) (BARRETO, 2013).

A Bioética e o Biodireito possuem, em comum, o objeto de estudo, isto é, as ciências biomédicas e a sua incidência no ser humano, embora com óticas diferentes: respectivamente, reflexão ética e jurídica, sendo, assim, indiscutível a relação entre ambos.

A pesquisa científica, em particular a experimentação humana em seres humanos, tem sido o principal motor do nascimento e desenvolvimento do Biodireito, como também da Bioética. Constitui, ao mesmo tempo, um exemplo de como a Ética e o Direito exercem influência recíproca. Enquanto a primeira consiste nos critérios e teorias sobre o comportamento correto; ou seja, numa prudência genética apta a enfrentar as complexidades do mundo atual, revelando-se como uma nova postura em relação ao mundo e às suas tecnologias, que visa, através de condutas responsáveis, a garantir a existência futura; o Direito consiste no caráter coercitivo, assim como na forma de se manifestar ou criar por intermédio da lei que se legitima quando emanada no seio de um Estado democrático (CASABONA, 2005).

É notória a necessidade de se preocupar com a limitação e a regulamentação das atividades centradas na manipulação genética, não só em nível nacional como internacional, 
o que somente é possível no contexto de uma constituição democrática que as interiorize, dando positividade aos valores dominantes de uma determinada sociedade, e produzindo, com base nisso, leis respaldadas pelo consenso da maioria.

Encontramo-nos, então, em um momento propício à reflexão sobre as relações da Ética com o Direito, e, especificamente, entre a Bioética e o Biodireito, pois, até então, nunca o homem teve à sua disposição a evolução e a modificação da sua espécie ou das demais formas de vida. Com o uso da técnica, surgiu para o homem esta possibilidade. Antes, a evolução humana e de toda a natureza era realizada por uma mutação produzida naturalmente, em que a ordem do todo era assegurada pela seleção natural.

Todavia, as transformações provocadas pela revolução biotecnológica não se limitam ao campo biomédico e agrícola, estendendo-se à engenharia, aos metais, aos produtos têxteis, papel, etc. Em todas essas áreas existem consequências jurídicas significativas e iniciativas de regulação, inclusive no tocante à questão do patenteamento das descobertas. Toda essa realidade resulta em profunda alteração no mundo do Direito (DANTAS, 2017).

Por fim, a Bioética aspira, como objetivo final, a contribuir para o Direito (o legislador, nesse caso) com orientações na área. Contudo, para este, o compromisso é maior, posto que deve contribuir com um critério nítido e, em princípio, unívoco, válido para a resolução de cada caso concreto.

\section{BREVE HISTÓRICO SOBRE A PROTEÇÃO DAS INVENÇÕES BIOTECNOLÓGICAS ATRAVÉS DAS PATENTES}

A exploração de recursos naturais vem servindo de base para a perpetuação das sociedades ao longo do tempo. A manipulação da natureza incluindo seres vivos, no entanto, sofisticou-se, alterando seu status: de matéria prima de construção de base material para sociedades industriais passou a fonte de experimentos de ciências e tecnologias avançadas. O debate acerca das condições de desenvolvimento e apropriabilidade das biotecnologias tem crescido no Brasil ao longo dos últimos anos, pois, apesar de agregar uma das maiores biodiversidades do planeta, a utilização e transformação de tais ativos naturais na geração de riquezas, especialmente através da promoção das biotecnologias, ainda pode ser considerada modesta frente ao potencial nacional.

No início da década de 1970, a partir do desenvolvimento da técnica do ácido desoxirribonucleico (DNA) recombinante, que possibilita a transferência de material 
genético entre organismos vivos por meios bioquímicos, o conceito de biotecnologia foi dividido em tradicional e moderna. Esta última, associada à possibilidade de obtenção de produtos e substâncias através de novas técnicas genéticas, indo além do cruzamento entre espécies já existentes na natureza (ZUCOLATO; FREITAS, 2013). A descoberta da molécula de DNA e o desenvolvimento das técnicas de transferência de material genético entre organismos vivos por meios bioquímicos representaram um marco na ciência.

Com o advento da biotecnologia moderna surgem discussões sobre os limites para a patenteabilidade e sobre a projeção de direitos econômicos sobre o corpo humano, orientados ao respeito à dignidade humana.

Não obstante o reconhecido impacto positivo da propriedade intelectual sobre a promoção tecnológica, existem argumentos contrários ao patenteamento de organismos vivos e/ou suas partes que evidenciam a necessidade de se realizar ajustes no sistema de patentes para que a criação intelectual seja enquadrada como invenção tecnológica, bem como enfrentar questões relacionadas à moralidade da propriedade sobre seres vivos (DIAS; CERDA, 2016).

Em 1871, pela primeira vez outorgou-se uma patente para um organismo vivo, uma levedura livre de germes patogênicos aperfeiçoando o processo de fabricação da cerveja, a Louis Pasteur, na França.

Em 1930, nos Estados Unidos, foi aprovado o Plant Patent Act, ou seja, lei de patentes farmacêuticas que permitiu patentear novas variedades de plantas excluindo plantas de propagação sexual e tubérculos.

Em 1969, foi julgado o caso Rote Taube, no Tribunal Supremo da República Federal Alemã em matérias civil e penal. O caso tratava da admissão do princípio da patenteabilidade de processos de natureza biológica com aplicação dos requisitos gerais (novidade, atividade inventiva e aplicação industrial). Um processo de melhoramento animal por meio de técnicas e seleções de cruzamento poderia ser matéria patenteável. No mesmo tribunal, em 1975, foi julgado o caso Bäckerhefe. A decisão determina que, para se patentear um microrganismo, este deve poder ser obtido a partir de um procedimento reprodutível (CHAMAS, 2009).

Em 1977, o caso Antamanid foi julgado no Bundespatentgericht - tribunal competente em matéria de propriedade industrial da Alemanha. Uma reivindicação para um decapeptídeo cíclico denominado Antamanid - uma substância de ocorrência na natureza, presente no fungo "green amanite" - foi concedida com base em desenvolvimento de técnica de isolamento e de preparação da substância, conferindo-lhe valor econômico. Os limites 
entre descoberta e invenção foram abordados nessa ocasião. Ficou claro que substâncias de ocorrência natural poderiam ser patenteáveis se elas fossem novas e tivessem sido isoladas por meios técnicos. O mesmo tribunal, em 1978, no caso Lactobacilos bavaricus, concedeu proteção para uma nova espécie de bactéria de ácido láctico, de ocorrência natural, mas previamente desconhecida. A intervenção técnica humana para reconhecimento e obtenção de maneira reprodutível contribuiu para o acolhimento do pedido (CHAMAS, 2009).

Alguns consideram que o marco jurídico internacional da concessão de patentes para organismos vivos ocorreu com a decisão da Suprema Corte Norte Americana em 1980, quando do patenteamento da bactéria Pseudomonas, com base no fato de que a bactéria patenteada fora produzida em laboratório, tendo como aplicação a degradação do óleo cru (ZUCOLATO; FREITAS, 2013).

No entanto, foi através da decisão da Suprema Corte Norte-americana, no caso Diamod versus Chakrabarty, que as perspectivas de proteção mais amplas (para cobertura de genes) começaram a tomar forma. $\mathrm{O}$ caso tratou de uma invenção relacionada à bactéria Pseudomonas genus modificada geneticamente, que apresentaria dois ou mais plasmídeos geradores de energia, capazes de degradar hidrocarbonetos de petróleo, útil em situações de derramamento de petróleo. O invento foi desenvolvido pelo microbiologista da General Eletric Ananda Mohan Chakrabarty. Em 1972, o pedido de patente foi rejeitado pelo United States Patent and Trademark Office, uma vez que seu objeto foi considerado produto da natureza (SHIVA, 2002).

A Suprema Corte dos EUA decidiu, em junho de 1980, conceder a patente entendendo que a bactéria que ele criou era um novo produto ou um novo material sintético resultado da inteligência humana, e sendo assim, se tratava de um trabalho humano e não da natureza. Também decidiu que o enfoque principal sobre o qual se deve abordar essas questões sobre a matéria viva e a propriedade industrial consiste em verificar se o processo ou o produto é um invento da inteligência humana ou se consiste em um produto da natureza (MYSZCZUK; MEIRELLES, 2014).

A decisão partiu da análise do Título 35 do U.S.C 101 do Código dos Estados Unidos relativo à lei de patentes - base legal norte-americana que busca promover a proteção sobre as criações intelectuais - determinando que o intérprete da lei não deveria criar limitações à patente não expressas pelo legislador, visto que os termos utilizados (manufacture, composition of matter e any) indicariam um escopo de interpretação ampla. A decisão ressaltou "tudo o que está abaixo do sol pode ser patenteado" desde que haja a engenhosidade 
humana. A bactéria de Chakrabarty não ocorria naturalmente, portanto, não seria um produto da natureza, mas, sim, da inventividade do homem (BEAUCHAMP, 2013).

O caso Chakrabarty representou verdadeiro direcionamento paradigmático no tocante ao patenteamento de seres vivos, vez que consolidou o entendimento quanto à possibilidade dessa proteção, desde que enquadrados como produto ou composição de matéria manipulada pelos seres humanos.

A concessão de patentes relativas a seres vivos, todavia, ainda é objeto de fortes controvérsias. A principal dificuldade reside na diferenciação entre uma descoberta e uma invenção. Em determinada linha argumentativa, as pesquisas biológicas e da engenharia genética geram descobertas, e não invenções, já que atuam na recombinação de materiais genéticos preexistentes ou no isolamento de substâncias que ocorrem na natureza e, deste modo, não atenderiam aos critérios da patenteabilidade: novidade, atividade inventiva e aplicação industrial (ZUCOLATO; FREITAS, 2013).

Os modelos tradicionais de propriedade intelectual não aceitam proteger recursos genéticos, tais como se encontram na natureza por serem considerados descobertas. Este foi um dos aspectos que gerou maior debate no Encontro Internacional sobre o Projeto Genoma Humano em 1993. Os participantes declararam que o corpo humano, por respeito à dignidade da pessoa, não deve ser suscetível à comercialização. Não obstante, permitir-se-á a disponibilidade gratuita e controlada com fins terapêuticos ou científicos. Os conhecimentos genéticos são patrimônio da humanidade e devem ser comunicados livremente (CASABONA, 1999).

As descobertas sobre as sequências de DNA e de produtos derivados deram lugar ao questionamento da necessidade de sua proteção jurídica no marco mais amplo da patenteabilidade da matéria viva em geral. A importância econômica do direito de patentes, que comporta o direito de propriedade exclusivo sobre o objeto que recai a patente, impedindo que outros possam se utilizar sem a autorização daquele, levou ao debate sobre a conquista do seu reconhecimento sobre as sequências de DNA e procedimentos de terapia gênica, assim como já vem sendo feito com produtos farmacêuticos (CASABONA, 1999). 


\section{O PATENTEAMENTO EM BIOTECNOLOGIA NO ORDENAMENTO JURÍDICO BRASILEIRO}

O Brasil possui amparo legal para invenções desde 1809 e foi um dos membros fundadores da Convenção da União de Paris de 1883, tendo aderido a todas as suas revisões.

Após muitos debates, encerrou-se , em 1996, o processo de revisão do Código de Propriedade Industrial (Lei 5.772/71), com a promulgação da Lei da Propriedade Industrial (Lei 9.279/96), que ampliou o escopo das matérias patenteáveis, estabelecendo a possibilidade de proteção de todos os campos tecnológicos, alterando a proibição da lei anterior quanto, por exemplo, a substâncias, matérias, misturas ou produtos alimentícios, químico-farmacêuticos e medicamentos, de qualquer espécie, bem como os respectivos processos de obtenção ou modificação.

A nova lei passou a atender também às exigências do Acordo TRIPS, em relação ao patenteamento da Biotecnologia. Com início em 1996, em Punta Del Leste, e encerramento em Marraquexe, Marrocos, em abril de 1994, o fechamento da Rodada do Uruguai culminou com a criação da Organização Mundial do Comércio (OMC) e com a assinatura do Acordo TRIPS, com o objetivo de reduzir as distorções e obstáculos ao comércio internacional, além do estabelecimento do marco regulatório para a propriedade intelectual, tendo em vista a sua relação com o desenvolvimento dos países. A elaboração do TRIPS foi fruto de um acirrado debate, já que países em desenvolvimento, como o Brasil e Coreia do Sul, tinham muitas restrições à proposta de proteção à propriedade intelectual. Pressões dos Estados Unidos, Japão e Estados Europeus permitiram a aprovação do Acordo. Por outro lado, a adesão ao documento garantiria o acesso ao mercado internacional.

O Acordo TRIPS fixa o conjunto de regras mínimas a serem adotadas pelos EstadosMembros da Organização Mundial do Comércio. Os Estados não precisam conceder patentes além do mínimo obrigatório previsto pelo acordo e podem expandir os direitos de propriedade intelectual conforme seus interesses. A decisão de conceder ou não patentes além do mínimo previsto pelo Acordo TRIPS é uma decisão política e não de técnica jurídica de patente ${ }^{3}$.

A patente constitui um título outorgado pelo poder público - no Brasil, o Instituto Nacional da Propriedade Industrial (INPI) - àquele que desenvolveu uma invenção,

\footnotetext{
${ }^{3}$ Ver artigo 1.1 do Acordo TRIPS.
} 
atribuindo-lhe o direito de exclusividade na exploração desta, por período limitado ${ }^{4}$, contado da data de depósito no INPI, desde que presentes os requisitos da novidade, atividade inventiva e aplicação industrial (art. $8^{\circ}$ da Lei 9.279/96).

Trata-se de um título atributivo do exercício de propriedade outorgado pela autoridade pública, atendendo-se certas condições, ao autor ou titular de um invento, conferindo um direito exclusivo à sua exploração, isso durante determinado tempo e em território delimitado, exceto nos casos previstos em regras extraterritoriais. Sendo assim, a patente constitui um direito que é de propriedade, porém, com particularidades específicas.

Caso o titular não requeira a patente, o direito de propriedade e de exploração exclusiva inexiste. A invenção, no sistema jurídico brasileiro, somente será reconhecida como tal e assim protegida por nosso ordenamento legal se patenteada.

A patente pode ser de invenção ou modelo de utilidade, ou seja, quanto a sua finalidade, elas podem ser: patentes de invenção ou de modelo de utilidade. A lei brasileira não apresentou o conceito de invenção, deixando essa tarefa a cargo da doutrina. A explicitação do conceito jurídico de invento, praticamente, é evitada em vários países, havendo os que anunciam termos vagos, já que ele envolve mais aspectos técnicos do que jurídicos.

Para Gama Cerqueira, a invenção, pela sua origem, caracteriza-se como uma criação intelectual, como o resultado da atividade inventiva do espírito humano; pelo modo de sua realização, classifica-se como uma criação de ordem técnica; e, pelos seus fins, constitui um meio de satisfazer às exigências e necessidades práticas do homem (CERQUEIRA, 1982).

A invenção é, então, uma solução técnica para um problema técnico. Vale dizer, a proteção da patente existe apenas para um determinado tipo de criação, uma ação humana, que importa em intervenção na natureza, sendo assim ao mesmo tempo útil e de cunho concreto. Ou seja, a criação, para pretender a patente, deverá gerar uma solução técnica para um problema técnico (POZ; BARBOSA, 2009).

Para Gama Cerqueira, importante se faz diferenciar invenção de mera descoberta. A invenção, de modo geral, consiste na criação de uma coisa até então inexistente; a descoberta é a revelação de uma coisa existente na natureza. A invenção apresenta-se como a solução

\footnotetext{
${ }^{4}$ Art 40 da Lei 9.279/96 - O período de exploração exclusiva é de vinte anos, contados da data do depósito, ou, no mínimo, de dez anos a contar da data de concessão, ressalvada a hipótese de o INPI estar impedido de proceder ao exame de mérito do pedido, por pendência judicial comprovada ou por motivo de força maior.
} 
de um problema técnico, que visa a satisfação de fins determinados, de necessidades de ordem prática; a descoberta, ao contrário, não visa a fins práticos preestabelecidos e apenas aumenta a soma dos conhecimentos do homem sobre o mundo físico (CERQUEIRA, 1982).

Quanto à patente de modelo de utilidade (MU), a sua definição encontra-se na própria Lei 9.279/96 no art $9^{\circ} 5$. Esta modalidade de patente está associada a uma melhoria funcional no uso ou fabricação de "objetos conhecidos", ou seja, possui um menor grau de inventividade e, por isso, goza de um período de proteção menor que as patentes de invenção.

Para haver uma invenção ou modelo de utilidade patenteável, é necessário: novidade, atividade inventiva e aplicação industrial. Esses conceitos não são definidos nas normas internacionais, o que foi negociado pelos países, procurando dar maior liberdade de ação aos escritórios nacionais de patentes, buscando o desenvolvimento nacional em função das realidades domésticas.

A este ponto cabe a pergunta: a partir de que momento o ser vivo pode entrar no campo da patenteabilidade, ou seja, quando fenômenos biológicos se tornam invenções?

Scheuchzer (2002) define as invenções biotecnológicas como aquelas invenções que recaem sobre um produto composto de matéria biológica, ou que a contenha, ou sobre um procedimento que permite produzir, tratar ou utilizar a matéria biológica, ou seja, trata-se de um produto que a natureza não poderia produzir por si mesma. Com este critério as manipulações (seleção, extração, clonagem) de sequências de DNA, deixam de ser descobertas e passam a ser produto industrial.

\section{RESTRIÇÕES A PATENTEABILIDADE NA LEGISLAÇÃO NACIONAL}

Além dos requisitos já citados, essenciais à configuração da invenção, é necessário avaliar a idoneidade do objeto para a sua patenteabilidade. $\mathrm{O}$ ordenamento jurídico impõe impedimentos à patenteabilidade, visto que, mesmo reunindo os requisitos para a invenção, a lei proíbe, por razões de ordem técnica ou de atendimento ao interesse público.

A lei brasileira de propriedade industrial faz uma distinção entre o que não se pode patentear por não ser considerado como invenção ou modelo de utilidade (art. 10 da Lei 9279/96) e o que não é patenteável por ser expressamente proibido, apesar de, por definição,

\footnotetext{
5 Art $9^{\circ}$ da lei 9.279/96 - É patenteável como modelo de utilidade o objeto de uso prático, ou parte deste, suscetível de aplicação industrial, que apresente nova forma ou disposição, envolvendo ato inventivo, que resulte em melhoria funcional no seu uso ou em sua fabricação.
} 
poder se constituir numa invenção ou modelo (art 18 da Lei 9279/96). Em princípio, tudo é invento, salvo as exclusões listadas no art 10 da LPI. Assim, em regra, é patenteável toda solução técnica para um problema técnico (invenção) que seja nova e não seja óbvia para um técnico no assunto.

Os artigos que se referem ao objeto de nossos estudos são:

Art. 10 - Não se considera invenção nem modelo de utilidade:

$[\ldots]$

I - descobertas

Não resulta, em si, da criação do homem, mas trata-se em geral, de alguma lei da natureza apenas identificada pelo homem, não podendo ser considerada invenção ou modelo. Porém, os meios para se chegar a descoberta e o seu uso podem, eventualmente, constituir matéria privilegiável (IDS, 2013).

IX - o todo ou parte de seres vivos naturais e materiais biológicos encontrados na natureza, ou ainda que dela isolados, inclusive o genoma ou germoplasma de qualquer ser vivo natural e os processos biológicos naturais.

Aqui o artigo está se referindo as descobertas, nas quais não houve processo criativo desenvolvido pelo homem que resulte em uma invenção. $\mathrm{O}$ mesmo se aplica quando o texto do artigo alude ao material biológico "encontrado na natureza", portanto não tocado pela criatividade do homem. O genoma ou germoplasma de qualquer ser vivo natural, que em outras palavras representa a estrutura básica dos seres vivos e não resultam de ato criativo do homem, não são considerados uma invenção. Apesar da exclusão explícita daquilo que é isolado da natureza, o processo usado para o isolamento, caso preencha os requisitos de patenteabilidade, poderá ser patenteado, uma vez que o artigo 18, que trata das invenções não patenteáveis, não os exclui da proteção patentária. (IDS, 2013).

De uma forma geral, quanto aos materiais biológicos meramente isolados, estes seriam meras descobertas, por não apresentarem diferença para os produtos da natureza. Desta forma, mesmo que não houvesse a exclusão legal, pelo inciso IX, do art 10, não haveriam de ser consideradas como invenção, com base no inciso I (DIAS; CERDA, 2016).

Em matéria de biotecnologia existe um liame muito tênue entre descoberta e inventividade. Os argumentos referentes à proibição do registro seguem na linha de que as inovações biológicas carecem de capacidade inventiva, originando-se da manipulação ou da recombinação de materiais genéticos preexistentes ou, ainda, do isolamento de produtos e 
substâncias que ocorrem na natureza, tratando-se, portanto, de descobertas, e não de invenções. Os que defendem a apropriação, por sua vez, afirmam que o sistema de patentes é a única forma de evitar o uso não autorizado de inovações biológicas, uma vez conhecidas pela concorrência (PARANAGUÁ; REIS, 2009).

Já no seu artigo 18, a Lei de Propriedade Industrial Brasileira determina não ser patenteável,

II - as substâncias, matérias, misturas, elementos ou produtos de qualquer espécie, bem como a modificação de suas propriedades físico-químicas e os respectivos processos de obtenção ou modificação, quando resultantes de transformação do núcleo atômico; e

III - o todo ou parte dos seres vivos, exceto os microrganismos transgênicos que atendam aos três requisitos de patenteabilidade - novidade, atividade inventiva e aplicação industrial - previstos no art. 8 e que não sejam mera descoberta.

Aqui, a Lei reconhece que seres vivos não encontrados na natureza podem constituir invenções, mas proíbe a sua patenteabilidade.

A norma brasileira prevê a impossibilidade do patenteamento de plantas, animais e genes, ou mesmo parte deles. O conceito de parte de um ser vivo não é delimitado de forma clara na norma. A única hipótese prevista de patenteamento de seres vivos é de microrganismos transgênicos. A norma brasileira segue os padrões mínimos do Acordo TRIPS, que são copiados pela maior parte dos países-membros.

Se de um lado, a LPI veda o patenteamento de seres vivos, com exceção de certos microrganismos transgênicos (bactérias, fungos, leveduras), por outro lado ela não exclui o patenteamento dos processos não naturais para a sua obtenção ou modificação e nem tampouco de genes e sequência de DNA, desde que presentes os requisitos do art 8 da Lei (IDS, 2013).

Em síntese, com a vigência da nova lei de patentes, microrganismos modificados pelo ser humano e processos biotecnológicos não naturais tornaram-se passíveis de proteção patentária (Lei 9.279/96, art.8 ), desde que atendidos os requisitos básicos da patenteabilidade. Essa norma guarda consonância com o art. 23.3b do Acordo TRIPS.

A legislação nacional é extremamente restritiva com relação ao patenteamento de seres vivos, porém, na medida em que o patenteamento de material biológico tem se mostrado como uma vantagem econômica competitiva, estudos devem ser realizados para 
analisar se as restrições da LPI, no seu artigo 18, às invenções biotecnológicas ainda devem existir, e, ao ampliar a proteção, quais seriam os limites éticos ao patenteamento da vida.

\section{LIMITES ÉTICOS AO PATENTEAMENTO EM BIOTECNOLOGIA}

O sistema de patentes, por gerar temporário poder de monopólio, se apresenta como potente instrumento de estímulo aos inventores, às empresas, às instituições de pesquisa e aos investidores, aumentando a produtividade e criando um ciclo positivo de incentivo à inovação, levando, assim, ao incremento do desenvolvimento da sociedade.

O Direito de Patente possui duplo benefício: aquele de estimular a atividade inventiva por meio do direito de exclusividade e, por outro lado, o de favorecer a disseminação no mercado de informações sobre aquela nova tecnologia. De igual modo, a patente, diferentemente das formas alternativas de proteção, maximiza a chance de retorno do capital investido, mesmo que num segundo momento, o que retroalimenta a busca de avanços tecnológicos e a prosperidade econômica. Sendo assim, a concessão de reserva legal, por um período de tempo previsto em lei, constitui um preço que a sociedade precisa estar disposta a pagar, a fim de promover o incentivo à atividade inventiva.

A expansão da biotecnologia, e por causa da novidade da matéria e da sua direta incidência sobre a vida, surge como relevantes os problemas éticos, com particular referência às consequências potencialmente incompatíveis com a tutela dos direitos fundamentais do homem.

Em princípio, a invenção biotecnológica tem direito à mesma forma de proteção de todas as invenções; ou seja, elas não apresentam diferenças substanciais em comparação às inanimadas, enquanto possuírem a possibilidade de satisfazer aos requisitos do sistema de patentes. A exclusão da patente para invenções biotecnológicas só se justifica se houver obstáculos legais ou éticos na verificação de sua concessão.

Quando o material biológico origina-se do homem, a dimensão ética definitivamente ganha vantagem, porque é uma questão de identificar critérios para inspirar escolhas normativas que venham a salvaguardar a dignidade da pessoa e da integridade do seu patrimônio genético. A exploração do material biológico de origem humana exige sempre o respeito aos direitos fundamentais e da dignidade humana (DI LELLA, 2013).

Argumentos de natureza ética contrários à patenteabilidade de seres vivos, principalmente ao código genético, baseados no fato de que organismos da natureza são 
criações de Deus, portanto, não podem ser objeto de propriedade, persistem e são frequentemente trazidos à tona como contraposição à liberdade de criação na área biotecnológica. Dentre eles, a noção religiosa baseada na obrigação do homem em preservar e respeitar a integridade da natureza e as criações de Deus e não atuar como criador de novas espécies de organismos vivos. Essa criação seria uma contravenção às leis divinas e uma usurpação aos materiais orgânicos fornecidos por Deus para a reprodução e evolução das espécies (DIAS; CERDA, 2016).

Reconhece-se a influência desse argumento para a interpretação e construção do regramento patentário às invenções biotecnológicas de diversos países, sendo notória na Lei de Propriedade Industrial brasileira pelo seu extremo caráter restritivo quando se trata do patenteamento de seres vivos.

Segundo Belcher e Hawtin (1991), há uma série de argumentos baseados em fundamentos metafísicos e teológicos que rejeita a ideia de que a humanidade deve mexer com a criação de Deus. À humanidade é confiada a responsabilidade de preservar a integridade da vida; a humanidade não deve tentar usurpar os poderes orgânicos, e, portanto, seria inadequado conceder uma patente para uma invenção que envolva material biológico.

De certa forma, os debates sobre os aspectos éticos em biotecnologia não excluem pensamentos ideológicos e religiosos. Segundo Caforio (2006, p.67)”, observa-se, amplamente, que entre ética e biotecnologia, as principais religiões possuem algum peso na opinião pública", e ele segue dizendo: "na relação entre a ética e a biotecnologia, havendo conflito entre elas, não existe absolutamente razão para que uma prevaleça sobre a outra".

Para Lever (2008, p.13-14), muitas pessoas se opõem ao patenteamento de genes porque entendem que os genes não devem ser considerados como propriedade, segundo uma concepção de valor moral, e refletem suas preocupações com a destruição de alguns habitats e formas de vida humanas. Aqueles que se opõem à propriedade de genes entendem que a sua comercialização seria uma ameaça à dignidade humana. "Porém, a verdadeira preocupação não estaria na comercialização e, sim, no que será feito com as cópias das partes do corpo humano".

É claro que, em matéria de biotecnologia e engenharia genética, problemas éticos, morais e religiosos devem ser levados em consideração, assim como limites à aplicação da engenharia genética e ao patenteamento, sem deixar de garantir, ao mesmo tempo, proteção jurídica para as invenções biotecnológicas. 
Pode-se afirmar que existe uma necessidade de se conciliar as exigências de regulamentação da pesquisa biotecnológica com o pedido de controle social do patenteamento da vida; ou seja, não se pode perder de vista a exigência de se garantir o respeito à vida e o direito à saúde.

Todas as formas de biotecnologia avançada são utilizadas seja na pesquisa científica seja na produção industrial. A biotecnologia já trouxe, e ainda trará mais no futuro, contribuições importantes para a proteção e cura na saúde, sendo utilizada nos alimentos, fármacos e meio ambiente. Portanto, um primeiro e importante ponto a se esclarecer, segundo Caforio (2006), é por que a bioética não pode avaliar de forma presuntiva e genérica a legalidade ou não da biotecnologia e de consequência a sua tutela através da patente, mas a bioética pode ocupar-se das aplicações técnicas das invenções biotecnológicas, devendo estabelecer parâmetros através dos quais se deve avaliar a legalidade ou não de uma simples invenção biotecnológica em relação ao seu uso.

A concessão de patentes para invenções biotecnológicas é pacífica; porém, surge uma dificuldade, do ponto de vista ético, sobre os seus limites, uma vez que se está lidando com vidas. É evidente que o legislador deve inserir limites ao agir humano, para tutelar interesses considerados superiores, como a dignidade humana e a integridade física, e, portanto, que não podem ser prejudicados pelos interesses científicos e técnicos.

A concessão de uma patente constitui não somente um juízo sobre a possibilidade técnica de desenvolvimento industrial através da criação patenteada, mas, sobretudo, um juízo de valor traduzido no fato de a invenção em questão ser útil ao bem comum. Assim, é importante pensar que, nos casos em que existe uma dúvida sobre a moralidade na exploração comercial de uma invenção, ou em que esta possa vir a violar bens supremos como a saúde, a vida, o ambiente, a biodiversidade, o órgão responsável deve rejeitar o pedido, proibindo o patenteamento de tal invenção. Porém, o problema de fundo em matéria patentária é exatamente saber quais seriam esses imperativos morais e, mais precisamente, a admissão de um conceito mais universal de pessoa humana, que compreende o homem em qualquer situação e em qualquer fase do seu desenvolvimento, ou até mesmo a formação do conceito de homem como uma entidade realizada, que depende do consenso social do momento (LEVER, 2008).

Nesse delicado debate social, a proteção jurídica das invenções biotecnológicas deve levar em consideração aspectos morais; ou seja, a concessão de uma patente para uma invenção não pode contrariar a dignidade humana, a ordem pública e os bons costumes, a 
tutela da saúde e da vida das pessoas e animais, a preservação dos vegetais e da biodiversidade e a prevenção de graves danos ambientais. Porém, não se pode ignorar que questões morais tendem, hoje, a ser bastante controvertidas, especialmente em matéria de biotecnologia.

De acordo com Pizzoferrato (2002, p.167):

\begin{abstract}
Trata-se de limites de controle social ao comportamento de caráter aberto e histórico, fruto de um balanceamento contínuo entre instâncias e valores em evolução no ordenamento jurídico [...]. A proteção à propriedade intelectual é um direito fundamental, na moderna democracia, mas no âmbito de um desenvolvimento equilibrado e sustentável em grado de conjugar avanços científicos, tecnológicos e progresso social.
\end{abstract}

$\mathrm{Na}$ realidade, é próprio o respeito à dignidade humana, que deveria constituir o parâmetro de base para julgar a licitude ou não das invenções em biotecnologia ${ }^{6}$. E este é, de fato, o critério colocado, por exemplo, pelo Conselho da Europa, a cuja disciplina deve se fazer referimento, para avaliar a contrariedade ou não aos princípios éticos das invenções em biotecnologia. Nesse sentido, a Convenção para a Proteção dos direitos do homem e da dignidade do ser humano, no confronto com a aplicação da biologia e da medicina do Conselho da Europa de 4 de abril de 1997, parte da consideração que:

a) É necessário proteger o ser humano, seja como indivíduo, seja na sua participação na espécie humana, e reconhecer a importância de assegurar a sua dignidade.

b) A dignidade humana poderá ser colocada em perigo por uso impróprio da medicina e da biologia.

c) O progresso da biologia e da medicina deve ser utilizado para benefício da humanidade.

d) O interesse e o bem-estar do ser humano devem prevalecer sobre o interesse da sociedade e da ciência.

De maneira mais extensa (ampliando os limites de ordem pública e bons costumes, além da restrita consideração da pessoa humana), pode-se buscar inspiração no próprio Acordo TRIPS, que no seu artigo 27 (2) estabelece: “os Estados membros podem excluir do patenteamento das invenções, cuja exploração comercial no seu território deve ser impedida, por motivos de ordem pública e moralidade pública, assim como para proteger a vida ou a

\footnotetext{
6 O respeito à dignidade, direito inviolável, que constitui condição para o reconhecimento dos valores intrínsecos do ser humano, se explica no campo biomédico no respeito a outros direitos, como o direito à integridade e inviolabilidade do corpo.
} 
saúde pública do homem, dos animais e dos vegetais e para evitar grave dano ao meio ambiente". Sendo assim, a ordem pública inclui a proteção à vida e à saúde do homem, e também dos animais, plantas e meio ambiente (CHIAVEGATTI; ZECA, 2006).

Está claro que esses valores são diretrizes que representam apenas um minimum standards, e será tarefa da legislação de cada Estado membro especificar ou eventualmente acrescentar. Este dispositivo concede efetivamente, às autoridades legislativas nacionais, ampla liberdade na aplicação do critério em exame.

De acordo com os termos atuais de debate científico sobre o assunto, existe consenso em nível internacional de que devem ser excluídas, de qualquer forma de proteção patentária, invenções sobre o ser humano como tal, ou que venham a modificar a sua identidade genética, a fim de garantir a integridade física e a dignidade do indivíduo.

A Diretiva Europeia 98/44/CE, base regulamentadora para a proteção de invenções biotecnológicas, traz importantes limites éticos no seu artigo $6^{\circ}$, seção 2 , excluindo da patenteabilidade o corpo humano, desde o momento da concepção e nas várias fases do seu desenvolvimento, bem como a mera descoberta de um dos seus elementos, incluindo a sequência total ou parcial de um gene, a fim de assegurar a dignidade e a integridade do ser humano. Isso resulta em uma proibição de patentear não só o corpo humano como um todo, mas também para seus elementos individuais, incluindo genes e sequências parciais de genes, que, no entanto, se tornam patenteáveis quando apresentam uma aplicação industrial, tendo que ser considerado, neste caso, não mais como descobertas, mas como invenções que trazem alguma utilidade concreta explorável industrialmente.

$\mathrm{Na}$ base da proibição não há razões éticas absolutas. Ao contrário do corpo humano como um todo, uma parte destacada é, de fato, suscetível à exploração comercial lícita, desde que não ofenda os direitos fundamentais à dignidade, integridade da pessoa e ao princípio da não comercialização do corpo humano. A patenteabilidade da parte separada do corpo humano não afeta, portanto, a proibição da patenteabilidade do corpo humano como um todo.

A norma patentária brasileira guarda consonância com os padrões mínimos do Acordo TRIPS, o qual permite que os países signatários excluam do patenteamento determinados inventos, como, por exemplo, aqueles que ofendam a moral ou a ordem pública. Nestes termos, a lei nacional prevê, no artigo 18, inciso I, disposição que reserva à autoridade registradora, isto é, ao INPI, tal competência. 
A atual Lei Patentária Nacional prevê que o exame daquilo que venha a ser considerado ofensivo à "moral" ou aos "bons costumes" seja feito pelo INPI (Instituto Nacional da Propriedade Industrial) ${ }^{7}$. A despeito da lei brasileira ser proibitiva em relação ao patenteamento de seres vivos, cogente ressaltar que inexistem critérios normativos que indiquem à autoridade administrativa soluções para delimitação de questões de cunho ético; isto é, não se encontra na legislação qualquer baliza apta a guiar a autoridade pública no estabelecimento de limites éticos.

Recolocando a questão, temos que, diversamente daquilo que ocorre na proteção em biotecnologia no âmbito da Diretiva Europeia, que estabelece um rol de limites éticos ao patenteamento de seres vivos, o arsenal legal brasileiro se ressente de uma tabula de valores norteadores da ação administrativa; ou seja, na medida em que a norma pátria não permite o patenteamento de seres vivos, o legislador não fez inserir na lei qualquer catálogo de valores hábil a guiar os agentes públicos.

Ao serem implementadas modificações no artigo 18, inciso III da LPI, possibilitando, destarte, a ampliação do patenteamento em biotecnologia, permitindo-se a proteção sobre seres vivos, inevitável será a eclosão de inúmeras discussões no campo ético.

Com a manutenção dos atuais critérios do artigo em comento, caberá exclusivamente ao INPI decidir sobre os limites éticos do patenteamento, uma vez que a lei lhe atribui competência para dizer o que se considera ofensivo à "moral" ou aos "bons costumes".

Outra possibilidade diz respeito a que tal alteração legislativa venha acompanhada da imposição ao INPI da obrigação de realizar consultas públicas no estabelecimento de diretrizes regulamentares capazes de nortear a atuação de seus agentes.

Ainda nessa vereda, outra hipótese aventada seria a atuação não apenas do INPI, mas do próprio Ministério da Indústria, Comércio Exterior e Serviços, de promover sucessivas audiências públicas para criar uma regulamentação que se encontre em consonância com os anseios da sociedade civil. Ampliando essa participação popular, seria possível pensar, ainda, na atuação interministerial, isto é, envolvendo-se adicionalmente, por exemplo, o Ministério da Saúde e o Ministério da Ciência e Tecnologia.

Uma quarta possibilidade seria a edição de uma lei ordinária pelo Congresso Nacional que estabelecesse os necessários limites éticos. Tal lei, por óbvio, poderia ser

\footnotetext{
${ }^{7}$ Autarquia federal vinculada ao Ministério da Indústria, Comércio Exterior e Serviços.
} 
precedida de amplo debate com a sociedade civil, colhendo-se o mínimo denominador comum da opinião pública acerca do tema.

O que importa nessa discussão é que os critérios éticos a serem erigidos se apresentem com a maior objetividade e transparência possíveis, não sendo questão que possa ser tratada de forma discricionária pela autoridade administrativa.

Por fim, importante destacar que o problema ético, aqui analisado, diz respeito à patenteabilidade das invenções biotecnológicas, relativa à compatibilidade ética do regime de privatização como um sistema profissional de produção. Isto significa dizer que a invenção biotecnológica já passou pela análise ética da pesquisa aplicada e da experimentação. ${ }^{8}$

\section{CONSIDERAÇÕES FINAIS}

Na medida em que o patenteamento de material biológico tem se mostrado como uma vantagem competitiva para os países que o permitem, alterações legislativas devem ser implementadas, em especial em relação ao artigo 18, inciso III, da LPI, que amplia a proteção sobre seres vivos, para que o Brasil possa se tornar competitivo no mercado internacional.

Ao modificar a LPI nos termos propostos no presente estudo, inúmeras discussões éticas serão suscitadas, e, portanto, aventam-se as seguintes possibilidades na busca de soluções:

Caberá exclusivamente ao INPI decidir sobre os limites éticos do patenteamento, uma vez que a atual lei lhe atribui competência para dizer o que se considera ofensivo à "moral" ou aos "bons costumes".

a) Outra possibilidade diz respeito a tal alteração legislativa, que venha acompanhada da imposição ao INPI da obrigação de realizar consultas públicas no estabelecimento de diretrizes regulamentares.

\footnotetext{
${ }^{8}$ Este último aspecto não é objeto desse estudo. Ao verificar as regras que disciplinam o patenteamento em biotecnologia, deve-se considerar que os interesses mencionados estão de certa forma conectados ao direito constitucional da liberdade de pesquisa científica e técnica, sendo assim, não pode ser restringido a limites demasiado estreitos ou frustrado por proibições puramente ideológicas, principalmente quando o retorno econômico não exclui, mas se funde com a obtenção de benefícios para o progresso do conhecimento científico. É necessário distinguir a fase da pesquisa, anterior e, portanto, diferente da disciplina da propriedade industrial, uma vez que pertencem a momentos juridicamente distintos.
} 
b) O Ministério da Indústria, Comércio Exterior e Serviços, ao qual está ligado o INPI, poderia promover sucessivas audiências públicas no intuito de criar a regulamentação necessária.

c) A regulamentação poderia advir, ainda, de atuação interministerial, isto é, envolvendo-se adicionalmente, por exemplo, o Ministério da Saúde e o Ministério da Ciência e Tecnologia.

d) Por fim, outra possibilidade que se mostra factível seria a edição de lei ordinária que estabelecesse os necessários limites éticos para o patenteamento de seres vivos.

O que importa em toda essa discussão é que os critérios éticos a serem erigidos se apresentem com a maior objetividade, transparência e segurança possíveis, não sendo questão que possa ser tratada de forma discricionária pela autoridade administrativa.

\section{REFERÊNCIAS BIBLIOGRÁFICAS}

BARBOSA, Denis Borges. Propriedade Intelectual: da Convenção de Paris ao Patamar do Novo Milênio. Revista da ABAPI, Rio de Janeiro, nº 52, maio/jun 2001.

BARRETO. Vicente de Paulo. Bioética, Biodireito e Direitos Humanos. In: $O$ Fetiche dos Direitos Humanos e Outros Temas. $2^{\text {a }}$ ed. Porto Alegre: Editora Livraria do Advogado, v. p. 267 - 292, 2013.

BEAUCHAMP, Christopher. Patenting Nature: a problem of history. Stanford Technology Law Review, vol.16, número 2, 2013, v. p. 257 - 312. Disponível em: <http://stlr.stanford.edu/pdf/patentingnature.pdf>. Acesso em: 09 set. 2017

BELCHER, Brian; HAWTIN, Geoffrey. A Patent on Life. Ownership of Plant and Animal Research. Ottawa: Internacional Development Research (IDRC), 1991.

BRASIL. Lei 9.279, de 14 de maio de 1996. Regula direitos e obrigações relativos à propriedade industrial. Disponível em: <http://www.planalto.gov.br/ccivil_03/leis/L9279.htm> Acesso em: 02 set. 2018.

BRASIL. Portal do Ministério do Meio Ambiente do Governo do Brasil. Disponível em: <http://mma.gov.br/biodiversidade/convenção-da-diversidade-biologica>. Acesso em: 20 nov. 2015.

CARVALHO, Carlos Eduardo Neves de. Melhoramento Vegetal no Brasil e a Lei de Biossegurança. Revista da ABPI, Rio de Janeiro, nº 131, v. p. 27 - 41, jul/ago de 2014. 
CASABONA, Carlos María Romeo. Do Gene ao Direito. Sobre as implicações jurídicas do conhecimento e intervenção no genoma humano. Trad. Fabrício Pinto santos. São Paulo: IBCCrim, 1999.

. O Direito Biomédico e a Bioética. In: CASABONA, Carlos Maria Romeo; QUEIROZ, Juliane Fernandes (coord.). Biotecnologia e suas Implicações Ético-Jurídicas. Belo Horizonte: Del Rey, v. p 13 - 38, 2005.

CERQUEIRA, João da Gama. Tratado de Propriedade Industrial v. I, $2^{\text {a } e d . ~ S a ̃ o ~ P a u l o: ~}$ RT, 1982.

CHAMAS. Claudia Inês. Propriedade Intelectual e Biotecnologia. In: IACOMINI. Vanessa (coord.). Propriedade Intelectual e Biotecnologia. Curitiba: Juruá, v. p. 71-92, 2009.

CHIAVEGATTI, Gian Andrea; ZECCA, Marco. Considerazioni Introduttive in Materia di Brevettabilità. In: BOSCHIERO, Nerina (org.). Bioetica e Biotecnologie nel Diritto Internazionale e Comunitario. Questioni Generali e Tutela della Proprietà Intellettuale. Torino: G. Giappicheli Editore, v.p. 189 - 198, 2006.

CAFORIO, Giusseppe. I Trovati Biotecnologici tra i Principi Etico-Giuridici e il Codice di Proprietà Industriale. Torino: G. Giappichelli Editore, 2006.

DANTAS, Ivo. A Era da Biotecnologia: Constituição, Bioética e Biodireito. Disponível em: <http://www.passeidireito.com/arquivo/11132760/a-era-da-biotecnologia >. Acesso em: 08 jan. 2017.

DIAS, José Carlos Vaz; CERDA, Clarisse De La. A Decisão Norte-Americana do Caso Myriad: novos paradigmas para a proteção patentária do código genético humano e biotecnologia. Revista de Direito Internacional, Brasília, v. p.513-535, v.13, n.3, 2016.

DI LELLA, Francesca. Logica del Profitto e Dimensione Etica nella Disciplina della Proprietà Industriale sulle Invenzione Biotecnologiche, v. p. 245 -266, 2013. Disponível em: http://www.juscivile.it Acesso em 05 fev. 2018.

FABRIZ. Daury Cesar. Bioética e Direitos Fundamentais: A bioconstituição como paradigma do biodireito. Belo Horizonte: Mandamentos, 2003.

IDS - Instituto Danneman Siemsen de Estudos Jurídicos e Técnicos. Comentários à Lei de Propriedade Industrial. $3^{\text {a }}$ ed. Rio de Janeiro: Renovar, 2013.

JOSAPHAT, Carlos. Ética Mundial: Esperança da humanidade globalizada. Petrópolis: Vozes, 2010.

LEVER, Annabelle. Is It Ethical to Patent Human Genes? In: GROSSERIES, Axel; MARCIANO, Alain; STROWEL, Alain (org.). Intellectual Property and Theories of Justice. Londres: Palgrave Macmillan, v. p. 246 - 264, 2008.

MARTÍNEZ, Stella Mara. Manipulação Genética e Direito Penal. São Paulo: IBCerim, 1998. 
MYSZCZUK, Ana Paula; MEIRELLES, Jussara Maria Leal de. Algumas Reflexiones sobre Patentes, Biotecnologia y sobre la Protección del Ser Humano en la Era Posthumana. In: CASABONA, Carlos María Romeo (Ed.). Aspectos Éticos Jurídicos de las Patentes Biotecnológicas: la dimensión patrimonial de la materia viva. Granada: Comares, v. p. 51 65, 2014.

PARANAGUÁ, Pedro; REIS, Renata. Patentes e Criações Industriais. Rio de Janeiro: FGV Jurídica, 2009.

PESSINI, Leo; BARCHIFONTAINE, Christian de Paul. Problemas Atuais de Bioética. 9a ed. São Paulo: Loyola, 2010.

POZ, Maria Ester Dal; BARBOSA, Denis Borges. Incertezas e Riscos no Patenteamento de Biotecnologias: A situação brasileira corrente. In: IACOMINI, Vanessa (coord.). Propriedade Intelectual e Biotecnologia. Curitiba: Juruá, v. p.93 - 138, 2009.

RIFIKIN, Jeremy. O Século da Biotecnologia. A valorização dos genes e a reconstrução do mundo. Trad. Arão Sapiro. São Paulo: Makron Books, 1999.

SCHEUCHZER, Antoine. L'Invention Brevetable en 2002, en Particulier les Logiciels, les Méthodes Commerciales et les Invention Genétiques. Bulletin d'Information $n^{\circ} 32$, fev. $2002 . \quad$ Disponível em: <http://www.unil.ch/files/live//sites/cedidac/files/Bulletins/Bulletin_no_34.pdf.> Acesso em: 14 jul. 2017.

SHIVA, Vandana. La Bio Piraterie ou le Pillage de la Nature \& de la Connaissance. Paris: Alias etc..., 2002.

PIZZOFERRATO, Alberto. Brevetto per Invenzione e Biotecnologie. Trattato di Diritto Commerciali e di Diritto Publico dell' Economia, v. XXVIII. Padova: CEDAM s.p.a, 2002, p.167.

TRIPS. Acordo sobre Aspectos dos Direitos de Propriedade Intelectual Relacionados ao Comércio de 1994. Disponível em: <https://www.wto.org/english/docs_e/legal_e/27trips_03_e.htm> Acesso em: 02 set. 2018

UE. Diretiva 98/44/CE do Parlamento Europeu de 6 de julho de 1988. Disponível em: http://www.cgcom.es/sites/default/files/54_Directiva_98_44_CE.pdf Acesso em: 02 set. 2018.

VARELLA, Marcelo Dias. Políticas Públicas para Propriedade Intelectual no Brasil. In: . (org.). Propriedade Intelectual e Desenvolvimento. São Paulo: Aduaneiras, v. p. $170-232,2005$.

ZUCOLATO, Graziela Ferrero; FREITAS, Rogério Edivaldo. Introdução. Propriedade Intelectual e Aspectos Regulatórios em Biotecnologia. Rio de Janeiro: IPEA, 2013. 
Quaestio Iuris

Trabalho recebido em 10 de março de 2019

Aceito em 04 de dezembro de 2020 